\title{
A Talk on Modern Art Periodicals
}

\section{ARTHUR H. MINTERS}

[Editor's note-The following article presents the highlights of a talk given by Mr. Minters at the City Art Museum in St. Louis in the summer of 1964. The original talk was illustrated with lantern slides. Of the fortyone periodicals mentioned by Mr. Minters, thirty or more, in complete or partial runs, are presently among the holdings of The University of Iowa Libraries.]

The journal Camera Work, ${ }^{1}$ edited by Stieglitz, contributed to making photography an independent art. Liberated from the realistic prerequisite of portraiture, photography could be developed for more important uses. Painting also was freed from this burden. The concepts behind the work of Stieglitz, his Gallery "291," and the group of young artist-photographers who contributed to his magazine led to the discovery of photography for more than recognition. Steichen, Man Ray, Marius de Zayas and the European artists whose work Stieglitz showed all experimented with materials and techniques, creating new media. Stieglitz introduced the "masses" as an iconographic subject, an innovation which in turn influenced the Soviet film directors, who used this subject for political purposes. In fact, almost all of the titles mentioned below have this propagandistic aspect inherent in their structure. They share a reliance on structure to carry their impact. The format, paper, binding and contents, whether printed or illustrative, combine to create a unity. This unity, in turn, provides an ambiance that can be called a new reality, a reality beckoning the viewer to look at the page in a different way, as a whole new work of art. The insecurity of the period is somewhat diminished by this

${ }^{1}$ Camera Work; a Photographic Quarterly. New York: 1903-1917. 
formal organization of elements producing an artistic order lacking in the outside world. The photograph is now independent of the accompanying text; it exists on its own merit. It helps us to appreciate the honesty of the two dimensional in art-spatially. It leads the way to our respect for the printed page as a two dimensional object as well as for the canvas.

Ver Sacrum, ${ }^{2}$ published in Vienna from 1898 until 1903, is another journal which reflects this new reality. Incorporating the elements of the Art Nouveau from London, Paris, and Munich, it synthesizes them and produces a two dimensional black-and-white effect in the contributions of Klimt, Olbrich, and Hoffmann. These strong geometric designs in two colors parallel the work of the young Freud in his attempt to understand the relationship between the conscious and the unconscious. From Vienna, the development of the two dimensional unity in space and design influenced the work of the Bauhaus, the Constructivists, and the De Stijl movements and their publications.

Barcelona at the turn of the century provided its artists and writers with an atmosphere of intellectual excitement because of its rapid growth in commerce and science. The northern European influences were digested from periodicals such as The Studio, ${ }^{3}$ La Revue Blanche, Gil Blas ${ }^{5}$ and La Plume, ${ }^{8}$ From journals like Pel y Ploma, Forma, ${ }^{8}$ Arte Joven, ${ }^{9}$ and Joventut, ${ }^{10}$ the Art Nouveau seeped into the works of Nonell, Picasso, Casas, and Rusiñol. Picasso took this influence to Paris and contributed to reshaping the imagery of the fin-desiecle into the stronger structural concept of Cubism. These Catalan journals used the work of Nonell, who painted the returning refugees of the Spanish-American War, and provided a pioneering example of the disenfranchised which was to influence Picasso's Blue Period.

At this time, Italy, so long the tourist paradise, was beginning to revolt against passeist traditions. The young generation led by Marinetti, Papini, Prezzolini, and Soffici wanted to get Italy moving again

2 Ver Sacrum; Zeitschrift der Vereinigung Bildender Künstler Osterreichs. Vienna: $1898-1903$.

3 The Studio; an Illustrated Magazine of Fine and Applied Art. London: 1893- .

4 La Revue Blanche. Paris: 1891-1903.

5 Gil Blas Illustre. Paris: 1891-1903.

6 La Plume; Littéraire, Artistique, Historique, Sociale. Paris: 1889-1913.

7 Pel y Ploma. Barcelona: 1899-1904.

${ }^{8}$ Forma; Publicació Ilustrada d'Art Espanyol Antic $i$ Modern $i$ d'Obres Estranjeres Existants a Espanya. Barcelona: 1904-1908.

9 Arte Joven. Madrid: 1901.

10 Joventut; Peribdich Catalanista. Barcelona: 1900-1906. 
artistically and politically. In the periodicals Leonardo, ${ }^{11}$ Poesia, ${ }^{12} \mathrm{La}$ Voce, ${ }^{13}$ Lacerba, ${ }^{14}$ this anti-passeist and pro-war fever is most evident. Not since the Risorgimento had Italy been able to enter into such close contact with Europe. The Post-Impressionists, Symbolists, and Cubists contributed to Poesia and Lacerba. The Futurists founded their own presses and publishing houses. Edizione "La Voce," "Lacerba," and later Edizioni Futuriste di "Poesia" published the works of the Futurists. Their works were not only anti-passeist, but anti-establishment, aggressive, and politically proto-fascistic. In a series of over forty manifestos, published for the most part by "Poesia," the Futurists attacked everything from architecture to typography in the hope of uniting sound with sight in a dynamic two dimensional, black-andwhite world of word and image. It was to be heard and seen in London, where it influenced the Vorticists, and as far east as Moscow, where it had its profoundest effects. Boccioni, perhaps the leading artist and sculptor of the movement, wanted to destroy all the marble and monuments of Italy and replace them with structures made from the materials surrounding him-glass, iron, wood, concrete, cardboard. This was a Constructivist ideal shared by the Russian Supremacists, the French Cubists and Purists, the Bauhaus and De Stijl movements; they all wanted to put together a world that was blown apart by the Great War and reconstruct it to combine form with function.

Elan, ${ }^{15}$ published by Ozenfant during the war, combines the propagandistic with the optimistic Constructivist concepts. Later, it was followed by Esprit Nouveau, ${ }^{16}$ with Le Corbusier as an editor. The "new spirit" was all embracing-art, letters, science, aeronautics, planning, theatre. It was a formalistic attempt to stop the erosion caused by the war and the Dada solution. It was a kind of artistic salvation, the beginning of a new reality, to solve the problems of the post-war world by rational planning and design. It was a reaction to the shoddy, pseudo-styled furniture and additive architecture that was produced with built-in obsolescence, merely to sell. The Bauhaus Zeitschrift ${ }^{17}$ in Germany, De Stij ${ }^{18}$ in Holland, Bulletin de lEffort Mod-

11 Leonardo; Rassegna Mensile della Coltura Italiana. Rome: 1925-1929.

12 Poesia; Rassegna Internazionale. Milan: 1905-1909.

13 La Voce. Edizione Politica. Florence: 1915-1916.

14 Lacerba. Florence: 1913-1915.

15 L'Elan. Paris: 1915-1916.

16 L'Esprit Nouveau. Paris: 1920-1925.

17 Bauhaus. Dessau: 1927-1931?

$18 \mathrm{De}$ Stijl; maanblad gewijd aan de moderne beeldende vakken en kultur. Delft: $1917-1932$ ? 
erne ${ }^{19}$ in France are printed testimonies to this wish to unite design with function, to break down the distinction between the fine and applied arts, to realize the hope that the human being could solve his predicament with planning and organized experiments.

Yet other artistic expressions reflecting the dilemma of modern man -insecurity, inability to cope with the industrial age, problems of urban living, and dependency on external escapes-are manifest artistically in the Dada and later Surrealist movements.

Journals such as " 391 "20 edited by Picabia during and after the Great War incorporate the "ready-made" as an artistic expression. With Duchamp, Grosz, Heartfield, Arp, and Huelsenbeck, a series of Dada publications was published in Berlin, New York, Zurich, and Paris. Names like Der Dada, ${ }^{21}$ Der Blutige Ernst, ${ }^{22}$ Cabaret Voltaire, ${ }^{23}$ The Blind $\mathrm{Man}^{24}$ give us some indication of the movement's attitude toward artistic expression. It was not necessary to create-art was around; all one needed was the ability to recognize the object by isolating it, by separating it from its natural environment and placing it on a neutral or unnatural background where it would be discovered. Perhaps this trend started with Cubism's development of the collage, coupled with Dada's love for the machine age and its products of cylinder blocks, crank shafts, coat racks, urinals, electric bulbs, refined with an inscription that was not intended to clarify the object's meaning. The results were certainly humorous, dramatic, ironic, defiant, and final. "Take it or leave it" was the Dada attitude, and there was no going beyond this. Duchamp, in fact, decided to quit making art and play chess.

Influenced by the Dada attitude, but unwilling to accept its conclusions, the Surrealists hoped to achieve the solution in the world of the unconscious, in the dream, in making man natural by allowing his unconscious to dictate his wishes and desires, and by aligning the movement with the new world of revolution. This was an impossible solution since the unconscious and the discipline of revolution are not very compatible. In 1924, Naville, Péret, and later Breton, edited Révolution Surréaliste, ${ }^{25}$ to be followed in 1930 by Surréalisme au Serv-

19 Bulletin de l'Effort Moderne. Paris: 1924-1927.

20391 (Three-nine-one). Barcelona, New York: 1917-1924.

21 Der Darla. Berlin-Charlottenburg: 1919.

22 Blutige Ernst. Berlin: 1919.

23 Cabaret Voliaire. Zurich: 1916.

24 The Blind Man. New York: 1917.

${ }^{25}$ La Révolution Surréaliste. Paris: 1924-1929. 
ice de la Révolution, ${ }^{25}$ which was more politically motivated. In 1933, Skira published Minotaure ${ }^{27}$ which combined all the aspects of the movement, the political, the unconscious, the automatic, the paranoic, and the assemblage in the spirit of the United Front.

In 1926, Cahiers $d A r t^{28}$ was founded by Zervos. It became the most important journal for the development of contemporary art, including every point of view. The most comprehensive representations of all the movements are sumptuously assembled on coated paper with excellent plates and important contributors. It endeavored to provide historical precedent for the new movements by relating them to the activities of the past, thus contributing to the legitimizing of modern art.

After this period, most publications either show the influence of all the major movements, or are devoted exclusively to one of the main movements while hoping to retain the original ideals. The Constructivist tendency continued in publications such as Plastique, ${ }^{20}$ Architecture d'Aujourd'hui, ${ }^{30}$ and Art d'Aujourd'hui, ${ }^{31}$ Dada and Surrealist tendencies are evident in the Belgian publication, Variétés. ${ }^{32}$ In England, the London Bulletin ${ }^{33}$ was published by E. L. T. Mesens from 1938 until the beginning of the Second World War. Arson ${ }^{34}$ and Free Unions ${ }^{35}$ are Surrealist publications of the war period.

The American Surrealist journal View ${ }^{36}$ started in 1940 with the help of the Surrealists who were forced to leave Europe. View lasted until 1947, combining all the Surrealist tendencies as well as indigenous American painting and art. It brought together primitive and folk art, and included the first wave of American abstract artists. $V V V,{ }^{37}$ whose title was taken from the victory slogan of the Second World War, was sponsored by Breton and the small European group. It included works

\footnotetext{
26 Surréalisme au Service de la Révolution. Paris: 1930-1933.

27 Minotaure. Paris: 1933-1939.

28 Cahiers d'Art. Paris: 1926- .

29 Plastique. Paris: 1937-1939.

${ }^{30}$ Architecture d'Aujourd'hui. Boulogne-sur-Seine: 1930- .

31 Art d'Aujourd'hui. Boulogne-sur-Seine: 1949-1954.

32 Variétés. Revue Mensuelle Illustrée de l'Esprit Contemporaine. Brussels: 1928-

33 London Bulletin. London: 1938-1944?

34 Arson; an Ardent Review. (Surrea'ist Manifestation). London: 1912.

35 Free Unions. London: 1946.

36 View; "through the eyes of poets." New York: 1940-1947.

37 VVV [Poetry, Plastic Arts, Anthropology, Sociology, Psychology] New York: $1942-44$.
} 1930. 
by the group of artists identified with Peggy Guggenheim's gallery, "Art of this Century" and included Pollock, Motherwell, Hare, Baziotes, Gorky, and Rothko.

The French returning to Paris tried to re-establish their lost ground with publications such as Médium, ${ }^{38}$ Cimaise, ${ }^{30}$ and Derrière le Miroir, 40 but all of them have the "international" look of the Abstract Expressionists. In New York, It $I s^{41}$ displayed the results of the Eighth Street Group.

What has been discussed above is only a fragment of the intellectual migration of images and words that were set in motion in the late nineteenth century in Europe and America. These motifs spread to distant parts only to return to their place of origin as an artistic variation, and no single school or country can really claim to be most important. Primacy, if any, belongs to the individual contributor who had the courage to express his vision by making a statement, even though eventually modified. Here lies the hope and salvation of the independent artistic spirit in its most universal expression.

\footnotetext{
38 Médium; Communication Surréaliste. Paris: 1952-1955.

39 Cimaise; Revue de l'Art Actuel. Paris: 1953- .

40 Derrière le Miroir; Revue Mensuelle. Paris: 1947?- .

41 It Is. New York: 1958-1966?
} 


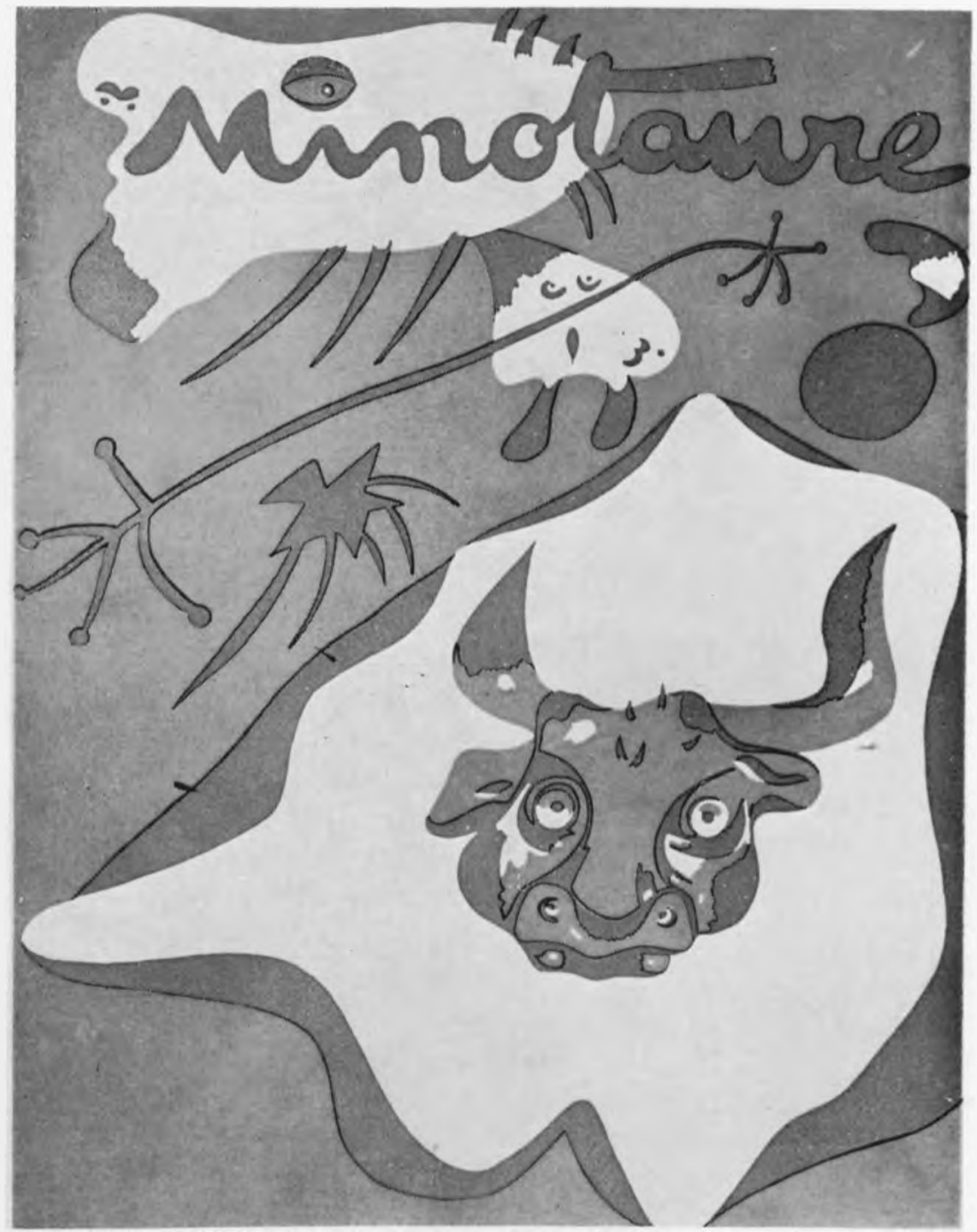

Cover of issue number five, 1935, of Minotaure, a periodical pulblished in Paris by Alluert Skira. 